EXAMINING THE Determinants OF MOBILE TECHNOLOGIES USE IN ACADEMIC SETTINGS BY LECTURERS AND STUDENTS IN TWO SAUDI ARABIAN UNIVERSITIES

\author{
By \\ Abdulelah Alshehri \\ University of Jeddah, Jeddah, \\ Saudi Arabia \\ Faculty of Education
}

Research Gournal Specific Fducation

Faculty of Specific Fducation

Mansoura University

ISSUE NO. 56, JANUARY, 2020

مجلة بحوث التربية النوعية - جامعة المنصورة

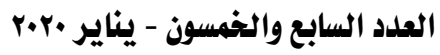




\title{
EXAMINING THE Determinants Of MOBILE TECHNOLOGIES USE IN ACADEMIC SETTINGS BY LECTURERS AND STUDENTS IN TWO SAUDI ARABIAN UNIVERSITIES
}

\author{
Abdulelah Alshehri*
}

\section{Abstract}

Mobile technologies are increasingly recognized for their potential to enhance teaching and learning practices both within and outside of the classroom. While a plethora of studies has been conducted in recent years on the uses and impact of mobile devices for learning in education settings around the world, such studies conducted in Saudi Arabian higher education institutions are lacking. The purpose of this study was to identify the determinants of mobile technology use for mobile learning by lecturers and students at two universities in Saudi Arabia. Besides, it aimed to discuss the features of mobile social networks (MSNs) that led lecturers and students to integrate these technological platforms into their academic lives. To understand the main factors determining the intention to use and behavioral usage of mobile technologies, the Unified Theory of Acceptance and Use of Technology (UTAUT) model was applied as a theoretical framework. An explanatory mixed-methods design was used in this study, comprising both quantitative and qualitative research principles to generate different perspectives on the research topic. An online questionnaire was employed to collect data on students' and lecturers' demographic characteristics, level of experience with the use of mobile technologies, and attitudes towards the use of mobile technologies to support the enhancement of teaching and learning. Data analysis was performed with SPSS version 23, including Exploratory Factor Analysis (EFA) using the principal component extraction method. Inferential statistical analyses were also conducted on the data including a multivariate ANOVA (MANOVA) and a series of Structural Equation Models (SEM). The main findings to emerge in this study are that performance expectancy and facilitating conditions affect

* University of Jeddah, Jeddah, Saudi Arabia, Faculty of Education 


\section{- Examining the Determinants of Mobile Technologies use in Academic settings}

technology use behavior. Students are generally more positive than lecturers about mobile device use for learning, although both groups regard mlearning devices to be mostly user-friendly and time-saving with the potential to improve their overall performance.

Keywords: Mobile devices, technology-supported learning, usertechnology relationships, individual difference factors

\section{Introduction}

Technology-supported learning is a facet of modern pedagogy that continues to demonstrate its potential to enhance educational effectiveness and efficiency [1]. Indeed, advanced technologies help to overcome a range of classroom limitations and provide a platform for new learning materials to meet a variety of learner needs [2]. Mobile devices are examples of popular advanced technologies increasingly used as supplementary tools in pedagogical practices, including the implementation of mobile learning (mlearning) programs [3]. Such devices have the potential to support learning outcomes by providing students and educators with the ability to access, store, and exchange information in any place and at any time, and to facilitate the creation of collaborative learning communities [4], [5].

Various definitions of m-learning have emerged to characterize the integral role it plays in education service delivery in educational institutions around the world. Some definitions focus on device characteristics, others on device mobility, and others again on the technological capabilities of the device [6]. This study characterizes m-learning as the integration of all these factors: the device, the mobility, and the capabilities to use the device to learn in various contexts.

Ongoing developments in portable devices m-learning contribute to the development of new teaching and learning strategies [7]. Such technologies afford educators and students new methods and opportunities to manage and utilize learning and teaching materials. In addition, advancing technologies offer new opportunities for knowledge management and collaborative learning practices [8]. It is therefore not surprising that 
mobile and other advanced technologies are increasingly prevalent in educational settings.

Research studies continue to identify the benefits of mobile technologies for work and study practices [9]-[11]. Students report the use of mobile devices for learning can increase their participation and engagement in academic tasks [12]-[14], and their motivation to learn. Furthermore, educators have reported the use of mobile devices for learning can increase their level of interactivity with their students and their classroom management practices [15].

Even though Saudi Arabia has one of the highest rates of mobile phone use, particularly among students and young people, the implementation of mobile devices for learning by academics is still in its initial stage [16]. Nonetheless, the adoption of learning technologies in education settings in Saudi Arabia is undoubtedly on the rise [16]. There are however still many gaps in the academic understanding of how best to implement them into pedagogical practices to maximize their effectiveness. Specifically, a deeper level of understanding is required in relation to how best to respond to ongoing innovation in the field, the anxiety factors associated with their use, and the cultural factors that may hinder the progress of mobile device usage for educational purposes [17].

Therefore, the current adoption of m-learning technologies among Saudi university students and educators is an important topic of research investigation. In response, this study aims to further investigate the drivers of mobile technology acceptance and uses for learning by Saudi lecturers and students. It also aims to identify and discuss the features of mobile technologies that facilitate students and lecturers to integrate them into their academic lives. Research of this kind into m-learning practices is important to better understand the scope of the field and how technological advances can be utilized to enhance and capacity of m-learning in educational institutions. The purpose of this paper is divided into two main points: 
- To examine the determinants of mobile technology use for mobile learning by lecturers and students at two higher education institutions in Saudi Arabia.

- To discuss the features of mobile social networks (MSNs) that lead lecturers and students to integrate them into their academic lives.

\section{Theoretical framework}

To identify the determinants of mobile technology use for mlearning by lecturers and students in higher education settings, this study illustrated on the Unified Theory of Acceptance and Use of Technology (UTAUT) model developed by [18] and the Technology Acceptance Model (TAM) initially developed [19]. Implied in the UTAUT model is that a person's intentions to use technology and his or her usage behaviors are dependent on eights key constructs that may be categorized in to two domains (see Figure 1): user-technology relationship factors including performance expectancy, effort expectancy, social influence, facilitating conditions; and individual difference factors including gender, age, experience, and voluntariness of use.

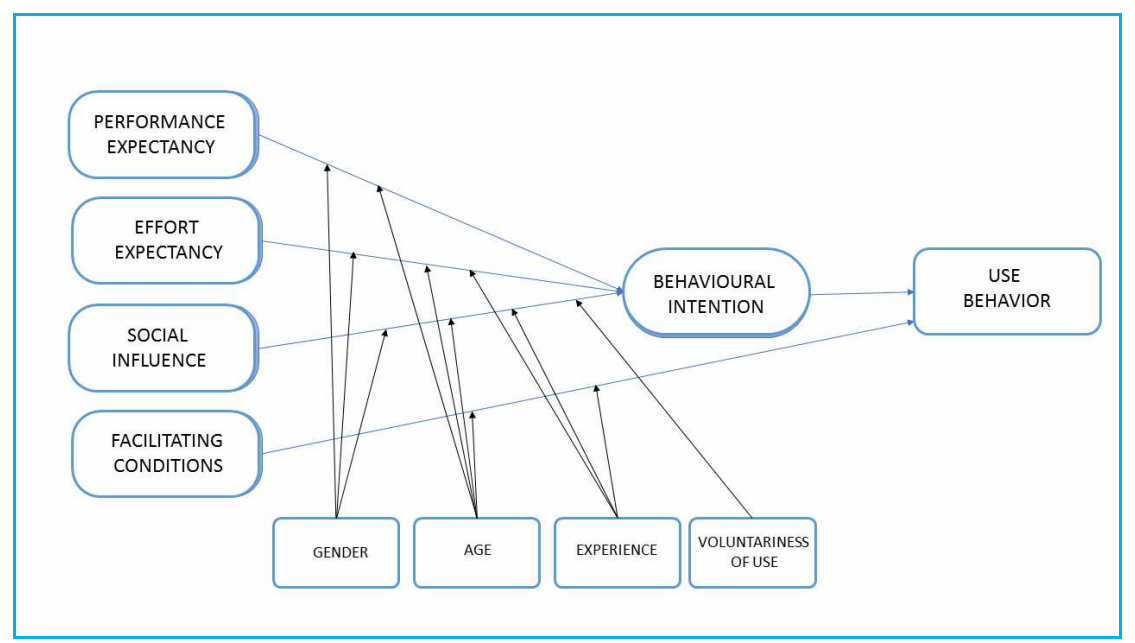

FIGURE 1. THE UNIFIED THEORY OF ACCEPTANCE AND USE OF TECHNOLOGY. 


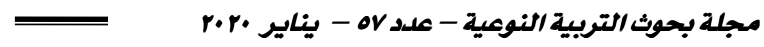

Two additional factors: self-efficacy and self-directedness (related to students only) were also included for investigation in this study under individual difference factors. Self-directedness was included for students only because it is related to how the student directs his or her own learning and there is no interest in comparing this with how educators lead their learning/teaching. As stated by [18], the four user-technology relationship factors may be considered as the direct predictors of technology use intentions and behaviors, and the four individual difference factors as the moderating effects on technology use intentions and behaviors. Table 2.1 presents some Conducted in the Context of Mobile Learning Technologies 


\section{- Examining the Determinants of Mobile Technologies use in Academic settings}

\section{Table 2.1 Summary of Research Conducted in the Mobile Learning Technologies Context}

\begin{tabular}{|c|c|c|c|c|}
\hline Reference & Authors & Aims/ objectives & Participants & Main findings \\
\hline [43] & $\begin{array}{l}\text { Ebner et al. } \\
(2010)\end{array}$ & $\begin{array}{l}\text { The aim of this study is to } \\
\text { investigate the use of a } \\
\text { microblogging platform for } \\
\text { process-oriented learning in } \\
\text { higher education }\end{array}$ & \begin{tabular}{|l}
- \\
-24 students \\
2 lecturers from Supply \\
Chain Management \\
Master's program at the \\
University of Applied \\
Sciences Of Upper Austria. \\
\end{tabular} & $\begin{array}{l}\text { The high level of communication mostly between students } \\
\text { suggests great potential for microblogging platforms } \\
\text { (without constraints) to support informal learning; namely, } \\
\text { learning through communicating on different topics. }\end{array}$ \\
\hline$[44]$ & $\begin{array}{l}\text { Lan \& Sie } \\
(2010)\end{array}$ & $\begin{array}{l}\text { The aim of this study is to } \\
\text { examine the use of RSS to } \\
\text { support M-learning }\end{array}$ & $\begin{array}{l}\text { - } 52 \text { freshmen students from } \\
\text { the Basic Programming } \\
\text { Design course at } \\
\text { Information } \\
\text { Management Department of } \\
\text { National } \\
\text { University, Taiwan. }\end{array}$ & $\begin{array}{l}\text { (1) The performance of SMS was better than Email and } \\
\text { RSS on content timeliness, and it is suitable for instant } \\
\text { information distribution. } \\
\text { (2) Email performs better than RSS and Email on content } \\
\text { richness, and it is applicable for extensive information } \\
\text { delivery. } \\
\text { (3) For the content accuracy and flexibility, RSS performs } \\
\text { better than others do. Therefore, RSS is suitable to support } \\
\text { front-end mobile devices to access and present content. }\end{array}$ \\
\hline$[45]$ & $\begin{array}{l}\text { Lawlor \& } \\
\text { Donnelly } \\
(2010)\end{array}$ & $\begin{array}{l}\text { The main idea of this study } \\
\text { is to investigate the use of } 7 \\
\text { different podcast formats to } \\
\text { improve the communication } \\
\text { skills among students in } \\
\text { doctoral research. }\end{array}$ & $\begin{array}{l}15 \text { first-year Science } \\
\text { Engineering } \mathrm{PhD} \text { research } \\
\text { students }\end{array}$ & $\begin{array}{l}\text { Students established a clear preference for podcast formats } \\
\text { that included summary key-point slides with explanatory } \\
\text { voice-over by the original speaker. }\end{array}$ \\
\hline$[46]$ & $\begin{array}{l}\text { Lazzari } \\
(2009)\end{array}$ & $\begin{array}{l}\text { The main objective of this } \\
\text { study is to examine the use } \\
\text { of an educational- } \\
\text { podcasting operation at } \\
\text { University of Bergamo } \\
\text { (Italy), with the aim to } \\
\text { enhance } \\
\text { environment. }\end{array}$ & $\begin{array}{l}\text { Undergraduate students (in } \\
\text { Human Computer } \\
\text { Interaction course at the } \\
\text { Faculty of Arts and } \\
\text { Philosophy at University of } \\
\text { Bergamo). }\end{array}$ & $\begin{array}{l}\text { Full-time (FT) students who were co-involved in lesson } \\
\text { podcasting outperformed FT students of previous years and } \\
\text { demonstrated higher levels of competitive agency. This } \\
\text { resulted in "better understanding of the theoretical issues } \\
\text { covered in the course and to more effective practical } \\
\text { skills". }\end{array}$ \\
\hline [47] & $\begin{array}{ll}\mathrm{Ng} & \& \\
\text { Nicholas } & \\
(2009) & \end{array}$ & $\begin{array}{l}\text { Examined integration } \quad \text { of } \\
\text { handheld computers (pocket } \\
\text { PCs) into schools in } \\
\text { Victoria, Australia }\end{array}$ & $\begin{array}{l}12 \text { teachers from three } \\
\text { primary schools and two } \\
\text { secondary schools located } \\
\text { in the northern and } \\
\text { eastern regions of } \\
\text { Melbourne, Australia. } \\
\text { Four schools were in low } \\
\text { socio-economic districts. }\end{array}$ & $\begin{array}{l}\text { Primary school teachers demonstrated mixed attitudes } \\
\text { about the educational benefits of pocket PCs; whereas } \\
\text { secondary school teachers demonstrated an attitude of } \\
\text { uncertainty. } \\
\text { Both primary and secondary school teachers shared similar } \\
\text { positive beliefs about the motivational aspect of pocket } \\
\text { PCs on student engagement, particularly for weaker } \\
\text { students and in English lessons, but not for the more } \\
\text { academic students. }\end{array}$ \\
\hline
\end{tabular}




\section{Methodology}

The study employed an explanatory mixed-methods study design. As such, both quantitative and qualitative research principles were applied to generate different perspectives of, and data outcomes related to the research topic for triangulation [20]. This paper reports the quantitative data results only.

\subsection{Settings and participants}

Two universities in Saudi Arabia were used as settings for this study: King Abdul-Aziz University in the western part of the country; and the King Khalid University, located in a number of towns including Abha, al-Namas, and Tanomah in the 'Asir Province in South-West Saudi Arabia.

The study sample comprised 191 lecturers $($ male $=99$; female $=92)$ and 209 students $($ male $=109$; female $=100)$ from both universities $($ King Khalid University = 222; King Abdul-Aziz University = 178). The students and lecturers were drawn relatively evenly from five faculties within each university: College of Education, Faculty of Arts and Social Science, Faculty of Computing and Information Technology, Faculty of Science, and Faculty of Law.

The ages of the students ranged from 18-26 years. Approximately $50 \%$ of the lecturers were aged between 25 and 34 years, and $37 \%$ were aged between 35 and 44 years. The majority of students (98\%) reported having attained a bachelor's degree; whereas the largest percentage of educators $(50 \%)$ were found to have a Master's degree, followed relatively closely $(42 \%)$ by those holding a Doctoral degree.

\subsection{Data collection}

The collection of quantitative data for this study was done via an online questionnaire. The items in the questionnaire supported data collection on the demographic characteristics of the participants including gender, age-range, IT skills, enrolment status, and level of experience with the use of mobile technologies; as well as their attitudes towards, and perspectives of, the use of mobile devices to enhance teaching and learning (adoption - See Appendix A). The questionnaire was a multi-item 
instrument with responses measured on a 5-point Likert-type scale ranging from: 1 (Never) to 5 (Always); or a 7-point Likert-type scale ranging from 1 (Strongly disagree) to 7 (Strongly agree).

\subsection{Data analysis}

The quantitative data were analyzed using SPSS version 23. Exploratory Factor Analysis (EFA) was performed using the principal component extraction method. Inferential statistical analyses were also conducted on the data, including a multivariate ANOVA (MANOVA) and a series of Structural Equation Models (SEM) to explore in further detail the relationships between the independent and dependent variables. A multivariate ANOVA (MANOVA) analysis of the data was performed to examine the extent to which the demographic variables of interest (gender and role) influence the UTAUT scale scores related to mobile device user experience. Usage experience for each cohort was grouped on a spectrum of experience. The scale scores were entered as dependent variables in the MANOVA, with the two demographic variables included as independent variables. The SEM analyses were performed to explore the extent to which the UTAUT model generalizes to the larger population-based upon the study sample. The analyses served to partially replicate a testable version of the UTAUT model as well as to test an extended model, which included a range of other attitudinal- and experience-based variables. Figure 2 illustrates the first SEM conducted: 


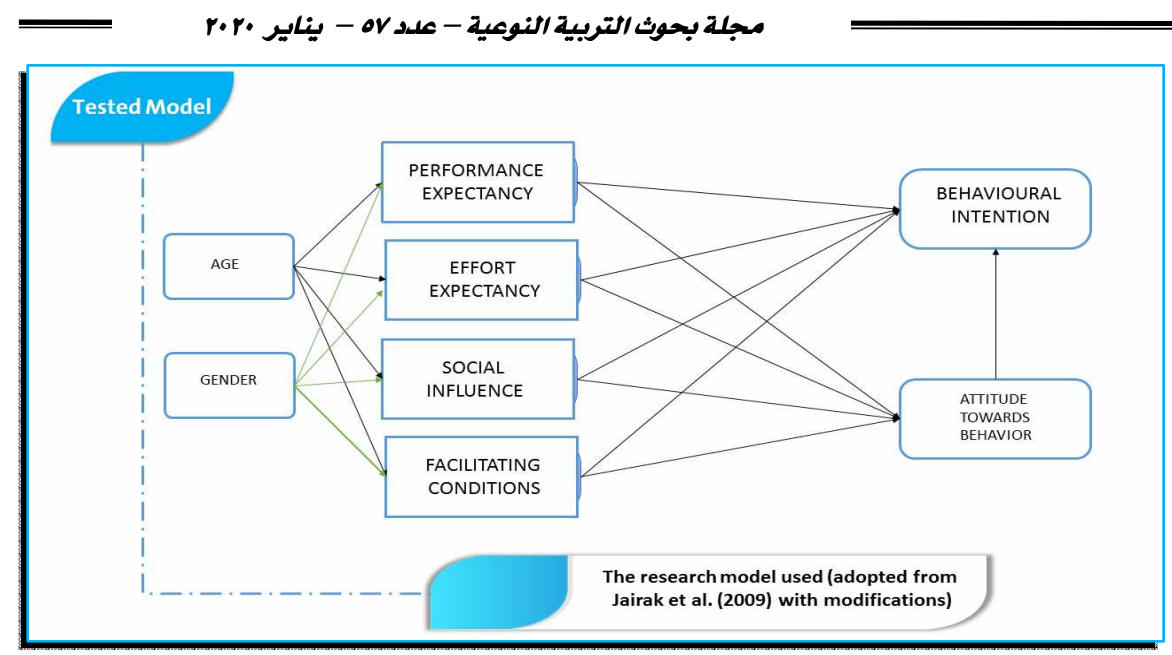

Figure 2. UTAUT model adopted from [21] with modifications

\section{Results}

The questionnaire instrument contained items to collect data on the demographic characteristics of the participants and their attitudes towards and perspectives of the use of mobile devices to support the enhancement of teaching and learning strategies.

\subsection{Background and experience}

Participants were asked to rate the frequency at which they performed seven activities on their mobile devices (see Table 1).

TABLE 1. MOBILE DEVICE ACTIVITIES: FREQUENCY OF PERFORMANCE

\begin{tabular}{|l|l|l|l|}
\hline \hline Mobile device activity items & N & Mean & SD \\
\hline \hline Add new friends to your social sites & 400 & 3.39 & 1.190 \\
\hline Follow friends' post on social sites & 400 & 3.73 & 1.190 \\
\hline Comment on friends' posts or re-tweet their tweets & 400 & 3.16 & 1.305 \\
\hline Add family members to your social sites & 400 & 3.65 & 1.248 \\
\hline Chat with friends via available chat tools in social sites & 400 & 3.58 & 1.389 \\
\hline Follow pages of famous people & 400 & 3.34 & 1.210 \\
\hline Post information you think may help others & 400 & 3.52 & 1.411 \\
\hline Mobile device activities scale score (average) & 400 & 3.48 & 0.972 \\
\hline \hline
\end{tabular}


The students and lecturers reported frequencies in the 'Sometimes' (3) to 'Often' (4) intervals. Table 1 shows the highest average frequencies were for 'Follow friends' posts on social sites' and 'Adding family members to your social sites'; whereas the lowest average frequencies were for 'Comments on friends' posts or re-tweet their tweets'. Overall, students undertook each of these activities more frequently than lecturers, with students reporting significantly higher frequencies on all activity items.

Participants were asked to rate the frequency at which they performed five learning activities on their mobile devices (see Table 2).

\section{TABLE 2. LEARNING ACTIVITIES USING A MOBILE DEVICE}

\begin{tabular}{||l|l|l|l||}
\hline Learning activity items & N & Mean & SD \\
\hline \hline Add class pages to your social sites & 397 & 2.90 & 1.413 \\
\hline Follow class posts on social sites & 400 & 2.88 & 1.410 \\
\hline Comment on class posts or re-tweet their tweet & 400 & 2.75 & 1.483 \\
\hline Add your class to your personal page & 400 & 3.46 & 1.381 \\
\hline Share academic information via social sites & 395 & 3.32 & 1.356 \\
\hline Learning activities scale score (average) & 392 & 3.04 & 1.203 \\
\hline \hline
\end{tabular}

The students and lecturers reported frequencies in the 'Rarely' (2) to 'Often' (4) intervals. Table 2 shows the highest average frequency was for 'Adding your class to your personal page'; whereas the lowest average frequency was for 'Comment on class posts or re-tweet their tweet'. Again, the students reported significantly higher frequencies on all learning activity items compared to the lecturers.

\subsection{User-technology relationship factors}

Participants were asked to rate five performance expectancy items related to mobile device use for learning (see Table 3). 
C r.r. مجلة بحوث التربية النوعية- عدد OV - r.

TABLE 3. PERFORMANCE EXPECTANCY AND MOBILE DEVICE USE FOR LEARNING

\begin{tabular}{|l|c|c|c|}
\hline Performance expectancy items & $\mathrm{N}$ & Mean & SD \\
\hline \hline Mobile devices are useful tools for learning & 400 & 6.18 & $\mathbf{0 . 8 1 2}$ \\
\hline $\begin{array}{l}\text { Mobile devices for learning allow students to complete } \\
\text { learning tasks more quickly }\end{array}$ & 400 & 5.89 & 1.359 \\
\hline $\begin{array}{l}\text { Students feel more productive in the course when using } \\
\text { mobile devices for learning }\end{array}$ & 400 & 5.59 & 1.353 \\
\hline $\begin{array}{l}\text { Mobile learning enables students to obtain better learning } \\
\text { outcomes }\end{array}$ & 400 & 5.34 & 1.557 \\
\hline $\begin{array}{l}\text { Learning performance improved with the use of mobile } \\
\text { learning devices }\end{array}$ & 400 & 5.53 & 1.492 \\
\hline Performance expectancy scale score (average) & 400 & 5.71 & 1.140 \\
\hline
\end{tabular}

The students and lecturers reported levels of agreement in the 'Slightly agree' (5) to 'Strongly agree' (7) intervals. Table 3 shows the highest average agreement was for 'Mobile devices as useful tools for learning'; whereas the lowest average agreement was for 'Mobile learning enables students to obtain better learning outcomes'.

Participants were asked to rate five effort expectancy items related to mobile device use for learning (see Table 4).

TABLE 4. EFFORT EXPECTANCY AND MOBILE DEVICE USE FOR LEARNING

\begin{tabular}{|l|l|l|l|}
\hline Effort expectancy items & N & Mean & SD \\
\hline \hline $\begin{array}{l}\text { Using mobile devices for academic purpose is an easy task for } \\
\text { me }\end{array}$ & 400 & 5.85 & 1.266 \\
\hline $\begin{array}{l}\text { I understand how to develop and create mobile learning } \\
\text { activities }\end{array}$ & 400 & 5.69 & 1.349 \\
\hline $\begin{array}{l}\text { Mobile learning enables students to become more skilful in } \\
\text { utilizing technology for academic purpose }\end{array}$ & 400 & 5.85 & 1.310 \\
\hline $\begin{array}{l}\text { Students understand how they can easily interact and } \\
\text { participate in mobile learning activities }\end{array}$ & 500 & 5.89 & 0.997 \\
\hline I can easily complete my assignment using my mobile device & 400 & 5.92 & 1.135 \\
\hline Effort expectancy scale score (average) & 400 & 5.84 & 1.011 \\
\hline
\end{tabular}




\section{- Examining the Determinants of Mobile Technologies use in Academic settings}

The students and lecturers reported level of agreement in the 'Slightly agree' (5) to 'Agree' (6) intervals. Table 4 reveals the highest average agreement was for 'I can easily complete my assignment using my mobile device', and the lowest average agreement was for 'I understand how to develop and create mobile learning activities'.

Participants were asked to rate five social influence items related to mobile device use for learning (see Table 5)

TABLE 5. SOCIAL INFLUENCE AND MOBILE DEVICE USE FOR LEARNING

\begin{tabular}{|l|l|l|l|}
\hline Social influence items & $\mathrm{N}$ & Mean & SD \\
\hline \hline $\begin{array}{l}\text { People who influence my behavior think that I should use } \\
\text { mobile devices for learning }\end{array}$ & 400 & 4.95 & 1.425 \\
\hline $\begin{array}{l}\text { I should use mobile devices for learning because people who } \\
\text { are important to me think that I should use it }\end{array}$ & 400 & 4.97 & 1.474 \\
\hline $\begin{array}{l}\text { I play the main role in the use of mobile devices for learning } \\
\text { and should be supportive of my classmates }\end{array}$ & 400 & 5.63 & 1.181 \\
\hline $\begin{array}{l}\text { I am likely to be well engaged in using mobile devices for } \\
\text { learning if my class supported its use }\end{array}$ & 400 & 5.65 & 1.354 \\
\hline $\begin{array}{l}\text { Using mobile technologies in my learning process does not fit } \\
\text { my learning culture }\end{array}$ & 400 & 3.94 & 2.171 \\
\hline Social influence scale score (average) & 400 & 5.03 & 1.156 \\
\hline
\end{tabular}

The students and lecturers reported level of agreement in the 'Slightly disagree' (3) to 'Agree' (6) intervals. Table 5 shows the highest average agreements were 'I play the main role in the use of mobile devices for learning and should be supportive of classmates', and 'I am likely to be well engaged in using m-learning if class supported its use'; whereas the lowest average agreement for 'Using mobile technologies in my learning process does not fit my learning culture' (i.e., for a negatively worded item).

Participants were asked to rate five facilitating condition items related to mobile device use for learning (see Table 6). 
مجلة بحوث التربية النوعية- علد ov - r.r. ميناير

TABLE 6. FACILITATING CONDITIONS AND MOBILE DEVICE USE FOR LEARNING

\begin{tabular}{|l|l|l|l|}
\hline Facilitating conditions items & $\mathrm{N}$ & Mean & $\mathrm{SD}$ \\
\hline \hline $\begin{array}{l}\text { I have the resources required to adopt mobile devices for } \\
\text { learning }\end{array}$ & 400 & 5.45 & 1.615 \\
\hline $\begin{array}{l}\text { I have the knowledge required to use mobile devices for } \\
\text { learning }\end{array}$ & 400 & 5.86 & 1.185 \\
\hline $\begin{array}{l}\text { Mobile devices used in learning are compatible with other } \\
\text { technologies I use }\end{array}$ & 400 & 5.46 & 1.582 \\
\hline $\begin{array}{l}\text { Assistance is available to solve any difficulty I meet when using } \\
\text { mobile devices for learning }\end{array}$ & 400 & 5.31 & 1.720 \\
\hline $\begin{array}{l}\text { The university has a plan to introduce and integrate mobile } \\
\text { technologies in education }\end{array}$ & 396 & 3.12 & 1.991 \\
\hline Facilitating conditions scale score (average) & 396 & 5.04 & 1.153 \\
\hline
\end{tabular}

Students and lecturers reported agreement levels in the 'Slightly disagree' (3) to 'Agree' (6) intervals. Table 6 reveals the highest average agreement was for 'I have the knowledge required to use mobile devices for learning'; whereas the lowest average agreement was for 'The university has a plan to introduce and integrate mobile technologies in education'.

Notably, when scores were treated as non-parametric and ordinal, the students reported significantly higher agreement compared to the lectures for all items across the four user-technology relationship factor categories except for the item, 'The university has a plan to introduce and integrate mobile technologies', in 'Facilitating conditions'.

\subsection{Individual difference factors}

Students were asked to rate their level of agreement for 11 selfdirectedness items related to mobile device use for learning (see Table 7). 


\section{- Examining the Determinants of Mobile Technologies use in Academic settings}

TABLE 7. STUDENT SELF-DIRECTEDNESS RELATED TO MOBILE DEVICE USE FOR LEARNING

\begin{tabular}{|l|l|l|l|}
\hline Student self-directedness items & $\mathrm{N}$ & Mean & SD \\
\hline \hline $\begin{array}{l}\text { In a mobile learning environment, I can manage my time well } \\
\text { and I can fix specific times to prepare mobile learning } \\
\text { activities }\end{array}$ & 209 & 6.06 & 1.163 \\
\hline $\begin{array}{l}\text { I can search out information more effectively using mobile } \\
\text { technologies }\end{array}$ & 209 & 6.33 & 1.337 \\
\hline $\begin{array}{l}\text { Using mobile devices for learning allows me to be systematic in } \\
\text { managing my learning time }\end{array}$ & 209 & 6.38 & 1.012 \\
\hline $\begin{array}{l}\text { Mobile devices for learning help me to enjoy learning new } \\
\text { information }\end{array}$ & 209 & 6.40 & 0.976 \\
\hline I believe I have a need to teach/learn via mobile devices & 209 & 6.14 & 1.285 \\
\hline $\begin{array}{l}\text { When presented with a problem I cannot solve while using } \\
\text { mobile devices for learning, I ask for assistance }\end{array}$ & 209 & 6.15 & 1.543 \\
\hline $\begin{array}{l}\text { In a mobile learning environment, I am responsible for my } \\
\text { own action }\end{array}$ & 209 & 6.43 & 1.017 \\
\hline $\begin{array}{l}\text { I prefer to set my own goals when using mobile devices for } \\
\text { learning }\end{array}$ & 209 & 5.99 & 1.546 \\
\hline $\begin{array}{l}\text { In a mobile learning environment, I would like to assess my } \\
\text { academic performance }\end{array}$ & 209 & 6.17 & 1.347 \\
\hline I am more focused on mobile learning activities & 209 & 5.98 & 1.362 \\
\hline Using mobile technologies, I can find information by myself & 209 & 6.21 & 1.209 \\
\hline Self-directed learning scale score (average) & 209 & 6.20 & 1.004 \\
\hline \hline
\end{tabular}

The students reported agreement levels in the 'Slightly agree' (5) to 'Strongly agree' (7) intervals. Table 7 shows the highest average agreements were for 'In a mobile learning environment, I am responsible for my own action', 'Mobile devices for learning help me to enjoy learning new information', and 'Mobile learning helps me to be systematic in managing learning time. In contrast, the lowest average agreement was for 'I am more focused on mobile learning activities.

Participants were asked to rate five self-efficacy items related to mobile device use for learning (see Table 8). 
TABLE 8. SELF-EFFICACY FOR MOBILE DEVICE USE FOR LEARNING

\begin{tabular}{|l|c|c|c||}
\hline \multicolumn{1}{|c|}{ Self-efficacy items } & N & Mean & SD \\
\hline \hline $\begin{array}{l}\text { I could complete the desired task using mobile technologies if } \\
\text { there was no one around me to direct my use of mobile devices } \\
\text { for learning }\end{array}$ & 5.62 & 1.223 \\
\hline $\begin{array}{l}\text { I could use technologies that support mobile learning, even if I } \\
\text { had never used such technology before }\end{array}$ & 400 & 5.72 & 1.407 \\
\hline $\begin{array}{l}\text { I could use technologies that support mobile learning if I had seen } \\
\text { someone else using it before trying it myself }\end{array}$ & 400 & 5.69 & 1.396 \\
\hline $\begin{array}{l}\text { Someone else needs to help me to use mobile devices to prepare } \\
\text { an academic task }\end{array}$ & 400 & 5.01 & 1.591 \\
\hline $\begin{array}{l}\text { I could complete the desired task using mobile technologies if I } \\
\text { had enough time to check the task for which the mobile } \\
\text { technology was designed }\end{array}$ & 5.92 & 1.020 \\
Self-efficacy scale score (average) & 400 & 5.59 & 0.919 \\
\hline
\end{tabular}

The students and lecturers reported agreement levels in the 'Slightly agree' (5) to 'Agree' (6) intervals. Table 8 reveals the highest average agreement was for 'I could complete the desired task using mobile technologies if I had enough time to check the task for which the mobile technology was designed'; whereas, the lowest average agreement was 'Someone else needs to help me to use mobile devices to prepare an academic task'.

Participants were asked to rate seven voluntariness of use items related to mobile device use for learning (see Table 9). 
- Examining the Determinants of Mobile Technologies use in Academic settings

TABLE 9. VOLUNTARINESS OF MOBILE DEVICE USE FOR LEARNING

\begin{tabular}{|c|c|c|c|}
\hline Voluntariness of use items & $\mathbf{N}$ & Mean & SD \\
\hline $\begin{array}{l}\text { Despite the benefits mobile learning provides, the use of mobile } \\
\text { technologies is not compulsory in my class }\end{array}$ & 400 & 5.46 & 1.511 \\
\hline My class does not require me to use mobile devices for learning & 400 & 5.25 & 1.523 \\
\hline It is not permitted to use mobile devices in the classroom & 400 & 5.71 & 1.555 \\
\hline I intend to use mobile devices for learning in the future & 400 & 5.85 & 1.424 \\
\hline I prefer to make mobile learning compulsory in my class & 400 & 5.23 & 1.863 \\
\hline $\begin{array}{l}\text { Students are allowed to bring their own devices and use them in } \\
\text { the classroom }\end{array}$ & 400 & 5.14 & 1.867 \\
\hline $\begin{array}{l}\text { I wish to use mobile devices for learning to improve the way } \\
\text { students learn my subject }\end{array}$ & 400 & 5.80 & 1.414 \\
\hline |Voluntariness of use scale score (average) & 400 & 5.49 & 1.024 \\
\hline
\end{tabular}

The lecturers and students reported levels of agreement in the 'Slightly agree (5) to 'Agree' (6) intervals. Table 9 shows the highest average agreements were for 'I intend to use mobile devices for learning in the future', and 'I wish to use mobile devices for learning to improve the way of learning students learn my subject. The lowest average agreement was for 'Students are allowed to bring their own devices and use them in the classroom'.

Participants were asked to rate five behavioral intention items related to mobile device use for learning (see Table 10). 
TABLE 10. BEHAVIORAL INTENTION TO USE MOBILE DEVICES FOR LEARNING

\begin{tabular}{|c|c|c|c|}
\hline Behavioral intention to use items & $\mathbf{N}$ & Mean & SD \\
\hline I intend to use mobile devices for learning in my acade & 400 & 6.19 & 0.974 \\
\hline I intend to use mobile devices for learning frequently & 400 & 5.86 & 1.358 \\
\hline I would like to be involved in mobile device based courses in the future & 400 & 6.14 & 1.127 \\
\hline $\begin{array}{l}\text { I support the idea that students bring their own devices to class and to } \\
\text { use them for their own learning purpose }\end{array}$ & 400 & 5.85 & 1.349 \\
\hline $\begin{array}{l}\text { I would recommend that others use mobile devices to improve access to } \\
\text { the course materials }\end{array}$ & 400 & 5.98 & 1.165 \\
\hline Behavioural intention scale score (average) & 400 & 6.00 & 0.970 \\
\hline
\end{tabular}

The students and lecturers reported levels of agreement in the 'Slightly agree' (5) to 'Strongly agree' (7) intervals. Table 10 reveals the highest average agreements were for 'I intend to use mobile devices for learning in academic life', and 'I would like to be involved in mobile device-based courses in the future'; whereas, the lowest average agreement was for 'I intending to use mobile devices for learning frequently'.

When scores were treated as non-parametric and ordinal, students reported significantly higher agreement than lecturers across all selfefficacy, behavioral intention to use, and voluntariness of use items, excepting; 'Despite the benefits mobile learning provides, the use of mobile technologies is not compulsory in my class'.

\subsection{Internal and external learning environment factors}

Participants were asked to rate four content access items related to mobile device use for learning (see Table 11).

\section{TABLE 11. CONTENT ACCESS WHEN USING MOBILE DEVICES FOR LEARNING}

\begin{tabular}{|l|c|c|c||}
\hline \multicolumn{1}{|c|}{ Content access items } & $\mathrm{N}$ & Mean & SD \\
\hline \hline Access the Internet for educational content through a mobile phone & 400 & 5.99 & 1.094 \\
\hline $\begin{array}{l}\text { Provide notifications or lecture notes via mobile social networks instead } \\
\text { of learning management system }\end{array}$ & 400 & 5.50 & 1.585 \\
\hline $\begin{array}{l}\text { Encourage student group discussion using mobile devices } \\
\text { Have lecture recordings available to students in audio or video }\end{array}$ & 400 & 6.06 & 1.139 \\
\hline Content access scale score (average) & 400 & 5.98 & 1.136 \\
\hline \hline
\end{tabular}




\section{- Examining the Determinants of Mobile Technologies use in Academic settings}

The lecturers and students reported levels of agreement in the 'Slightly agree' (5) to 'Strongly agree' (7) intervals. Table 11 reveals the highest average agreement was for 'Encourage student group discussion using mobile devices'; whereas the lowest average agreement was for 'Provide notifications or lecture notes via mobile social networks instead of learning management systems'.

Participants were asked to rate six academic communication items related to mobile device use for learning (see Table 12).

\section{TABLE 12. ACADEMIC COMMUNICATION WHEN USING MOBILE DEVICES FOR LEARNING}

\begin{tabular}{|l|c|c|c||}
\hline Academic communication items & Mean & SD \\
\hline $\begin{array}{l}\text { If I had mobile learning, I would develop better learning } \\
\text { resources than the current learning management system allows } \\
\text { by using web-based mobile applications }\end{array}$ & 5.64 & 1.377 \\
$\begin{array}{l}\text { Web-based mobile applications provide more flexible } \\
\text { communication than the current learning management system }\end{array}$ & 5.66 & 1.534 \\
$\begin{array}{l}\text { I encourage my classmates to use mobile social networks to share } \\
\text { academic knowledge }\end{array}$ & 500 & 5.68 & 1.501 \\
$\begin{array}{l}\text { If I could participate in mobile learning activities, I would } \\
\text { communicate better with my classmate than via face-to-face } \\
\text { communication }\end{array}$ & 5.91 & 1.306 \\
\hline $\begin{array}{l}\text { I prefer to use mobile social networks to communicate with the } \\
\text { students rather than the current learning system }\end{array}$ & 500 & 1.892 \\
\hline $\begin{array}{l}\text { Mobile learning activities allow me to communicate and interact } \\
\text { with the students better than face-to-face communication }\end{array}$ & 5.53 & 1.572 \\
\hline Academic communication & 400 & 5.61 & 1.241 \\
\hline
\end{tabular}

The students and lecturers reported agreement levels in the 'Slightly agree' (5) to 'Agree' (6) intervals. Table 12 shows the highest average agreement was for 'If I could participate in mobile learning activities, I would communicate better with my classmate than via face-to-face communication', and the lowest average agreement was for 'Mobile learning activities allow me to communicate and interact with the students better than face-to-face communication'. Participants were asked to rate seven quality characteristics of mobile learning (see Table 13). 
$\overline{\underline{ }}$ r.r. مجلة بحوث التريية النوعية - عدد OV - ميناير

TABLE 13. MOBILE DEVICE CHARACTERISTICS QUALITY

\begin{tabular}{|l|c|c|c||}
\hline Quality characteristics of m-learning & N & Mean & SD \\
\hline \hline $\begin{array}{l}\text { For m-learning to be effective, it is important for the service to } \\
\text { be error- free }\end{array}$ & 400 & 6.19 & 1.024 \\
\hline $\begin{array}{l}\text { For m-learning to be effective, it is important for the service to } \\
\text { be always available }\end{array}$ & 400 & 6.25 & 0.980 \\
\hline $\begin{array}{l}\text { For m-learning to be effective, it is important for the service to } \\
\text { provide fast downloads }\end{array}$ & 400 & 6.30 & 1.052 \\
\hline $\begin{array}{l}\text { For m-learning to be effective, it is important for content to be } \\
\text { easy to navigate }\end{array}$ & 400 & 6.32 & 1.095 \\
\hline $\begin{array}{l}\text { For m-learning to be effective, it is important for content to be } \\
\text { understandable }\end{array}$ & 400 & 6.25 & 1.099 \\
\hline $\begin{array}{l}\text { For m-learning to be effective, it is important for content to be } \\
\text { current }\end{array}$ & 400 & 6.25 & 0.941 \\
\hline $\begin{array}{l}\text { It is important that mobile learning services be personalized to } \\
\text { meet class needs }\end{array}$ & 400 & 6.30 & 0.889 \\
\hline Quality of mobile communication scale score (average) & 400 & 6.27 & 0.930 \\
\hline
\end{tabular}

Participants reported agreement levels in the 'Agree' (6) to 'Strongly agree' (7) intervals. Table 13 shows the highest average ratings were for 'For m-learning to be effective, it is important for content to be easy to navigate', and the lowest average ratings were for 'For m-learning to be effective, it is important for the service to be error-free'.

Participants were asked to rate 11 skills perceptions related to mobile device use for learning (see Table 14). 
TABLE 14. SKILL PERCEPTIONS FOR MOBILE DEVICE USE FOR LEARNING

\begin{tabular}{|c|c|c|c|}
\hline Skill perceptions items & $\mathbf{N}$ & Mean & SD \\
\hline $\begin{array}{l}\text { I would be anxious about using a mobile device to help support } \\
\text { academic work }\end{array}$ & 400 & 6.10 & 1.051 \\
\hline $\begin{array}{l}\text { I find it interesting to use and learn new technology to assist my } \\
\text { academic work }\end{array}$ & 400 & 6.16 & $\mathbf{1 . 0 5 7}$ \\
\hline $\begin{array}{l}\text { I could probably teach myself most things I need to know about } \\
\text { mobile devices }\end{array}$ & 400 & 6.19 & 0.958 \\
\hline I feel insecure about my ability to use mobile devices & 400 & 4.81 & 2.243 \\
\hline $\begin{array}{l}\text { I find I adapt quickly to the use of new mobile technology } \\
\text { features }\end{array}$ & 400 & 6.21 & 0.951 \\
\hline I can use mobile devices to do what I want to do & 400 & 6.05 & 1.154 \\
\hline $\begin{array}{l}\text { If I have a problem using a mobile device, I usually solve it one } \\
\text { way or another }\end{array}$ & 400 & 5.80 & 1.293 \\
\hline I am in complete control when I use mobile technologies & 400 & 5.89 & 1.326 \\
\hline Mobile technologies are sophisticated to use & 400 & 4.84 & 2.029 \\
\hline $\begin{array}{l}\text { I prefer to get help from someone who can tell me the best way to } \\
\text { use mobile technologies }\end{array}$ & 400 & 5.68 & 1.410 \\
\hline I like to discover new technologies by myself & 400 & 5.97 & $\mathbf{1 . 0 3 9}$ \\
\hline Skills on mobile devices scale score (average) & 400 & 5.79 & 0.946 \\
\hline
\end{tabular}

The students and lecturers reported levels of agreement in the 'Neither agree nor disagree' (4) to 'Strongly agree' (7) intervals. Table 14 reveals the highest average rating was for 'I find I adapt quickly to the use of new mobile technology features'; whereas the lowest average rating was for 'Mobile technologies are sophisticated to use.

Participants were asked to rate seven characteristics of mobile devices related to uses for learning (see Table 15). 
TABLE 15. MOBILE DEVICE CHARACTERISTICS FOR MLEARNING

\begin{tabular}{|c|c|c|c|}
\hline Mobile device characteristics items & $\mathbf{N}$ & Mean & SD \\
\hline mobile device with a sm & 400 & .19 & 107 \\
\hline $\begin{array}{l}\text { I support the idea of integrating social networks in my } \\
\text { teaching/learning because they are accessible via my mobile } \\
\text { device }\end{array}$ & 400 & 1 & 394 \\
\hline Current mobile devices are compatible with my course content & 400 & 5.39 & 1.486 \\
\hline the Internet at my university whenever I need it & 400 & 5.63 & 1.586 \\
\hline 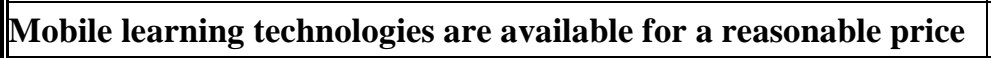 & 400 & 5.58 & 1.573 \\
\hline $\begin{array}{l}\text { I prefer to use mobile devices to access learning materials instead } \\
\text { of using a desktop computer because they are easy to access } \\
\text { whenever and wherever required }\end{array}$ & 400 & 6.04 & 1.282 \\
\hline \begin{tabular}{|lcc} 
With mobile learning technologies, I can complete \\
teaching/learning tasks and have them available in mobile devices
\end{tabular} & 400 & 5.97 & 1.162 \\
\hline Characteristics of mobile devices scale scor & 400 & 5.52 & 1.069 \\
\hline
\end{tabular}

The students and lecturers reported levels of agreement in the 'Neither agree nor disagree' (4) to 'Agree' (6) intervals. Table 15 shows the highest average rating was for 'I prefer to use mobile to access learning materials instead of desktop computer'; whereas the lowest average rating was for 'I prefer to use a mobile device with a small screen'.

When scores were treated as non-parametric and ordinal, students reported significantly higher agreement than lecturers across all content access, academic communication, quality of m-learning service, skills perceptions, and characteristics of mobile device items.

\subsection{MANOVA and SEM results}

The MANOVA test results for role, gender, and the two-way interaction between role and gender to predict the scale scores were all statistically significant. Role significantly influenced scores for 10 of the 12 scale scores included as dependent variables such that students obtained significantly higher scores than lecturers on these scales. Gender significantly influenced scores for five of the 12 scale scores included as dependent variables such that females obtained significantly higher scores 
than males on these scales. The two-way interaction between gender and role significantly influenced scores for four of the 12 scale scores included as dependent variables such that females obtained significantly higher scores than males on these scales. In terms of skills on mobile devices, females obtained higher scores than males, and students obtained higher scores than lecturers. In terms of the quality of mobile services, male students obtained the lowest scores and female students the highest scores. In terms of behavior intention scores, female students obtained higher scores than male students, and both female and male students obtained higher scores than either male or female lecturers. In terms of effort expectancy scores, female students obtained higher scores than male students, and both obtained higher scores than either male or female lecturers.

A structural equation model (SEM) with predictors, moderators, and outcome variables indicated that role (being a student) was significantly and positively associated with the three moderator variables plus the voluntariness of use outcome such that students appeared to be more likely than lecturers to obtain higher ratings. In contrast, gender (being female) was significantly and positively associated with the moderator, effort expectancy, and the outcome variable, behavioral intention such that females appeared to be more likely than men to obtain high effort expectancies and to intend to use mobile devices.

The associations between predictors, moderators and outcome variables included both direct and indirect pathways. Direct pathways for gender (being female) included those towards effort expectancy and behavioral intention, and direct pathways for students included those towards social influence, effort expectancy, performance expectancy, and voluntariness of use. Indirect pathways for gender (being female) and role (being a student) both included pathways towards voluntariness of use and behavioral intention. The strengths of these direct and indirect pathways were compared. For gender, the indirect pathway towards voluntariness of use and the direct pathway towards behavioral intention were each greater in magnitude than the corresponding indirect/direct effect. For role (being a 
student), indirect pathways towards both voluntariness of use and behavioral intention trumped the corresponding direct pathways.

A follow-up test involved an extended UTAUT model that included additional variables from the present dataset related to the impact of mobile learning components, with four of the five variables related to the impact of mobile learning components entered as additional moderators. For the purposes of this analysis, it was assumed that judgments about the impact of mobile learning components were influenced by performance expectancy, effort expectancy, and social influence variables. As one might expect, the parsimonious model included only some of the possible associations between the exogenous variables, moderators and outcome variables (see Figure 3). Of interest to this study is that neither role (being a student) nor gender (being female) retained any direct pathways to the two outcome variables: voluntariness of use and behavioral intention. It follows that one would expect the indirect pathways to be greater in magnitude in both cases (by default).

Gender (being female) included direct pathways to effort expectancy, quality of mobile service, academic communication, and content access, but not to voluntariness of use or behavioral intention. Role (being a student) included direct pathways to all variables except for voluntariness of use or behavioral intention. Gender (being female) and role (being a student) both included indirect pathways to characteristics of mobile use, quality of mobile service, academic communication, content access, the voluntariness of use and behavioral intention. For gender (being female), the indirect pathways to voluntariness of use and behavioral intention were by default greater in magnitude than the corresponding (nonsignificant) pathways. Likewise, the indirect pathway for gender to the characteristics of mobile use was greater in magnitude. However, the direct pathways between gender and quality of mobile service, academic communication and content access were each greater in magnitude than their indirect counterparts. For role (being a student), the indirect pathways to the voluntariness of use and behavioral intention were also by default greater in magnitude than the corresponding (non-significant) pathways. 


\section{- Examining the Determinants of Mobile Technologies use in Academic settings}

Beyond these pathways of primary interest, and with the exception of the indirect pathway between role and content access, other direct pathways (to quality of mobile service, and academic communication) were greater in magnitude.

In summary, after adding four variables related to the impact of mobile learning components as additional moderators, neither gender (being female) nor role (being a student) included direct pathways to the two outcome variables. It follows then that variables associated with the impact of mobile use on learning played an important role in explaining the effect of gender and role on the two outcomes (voluntariness of use, behavioral intention).

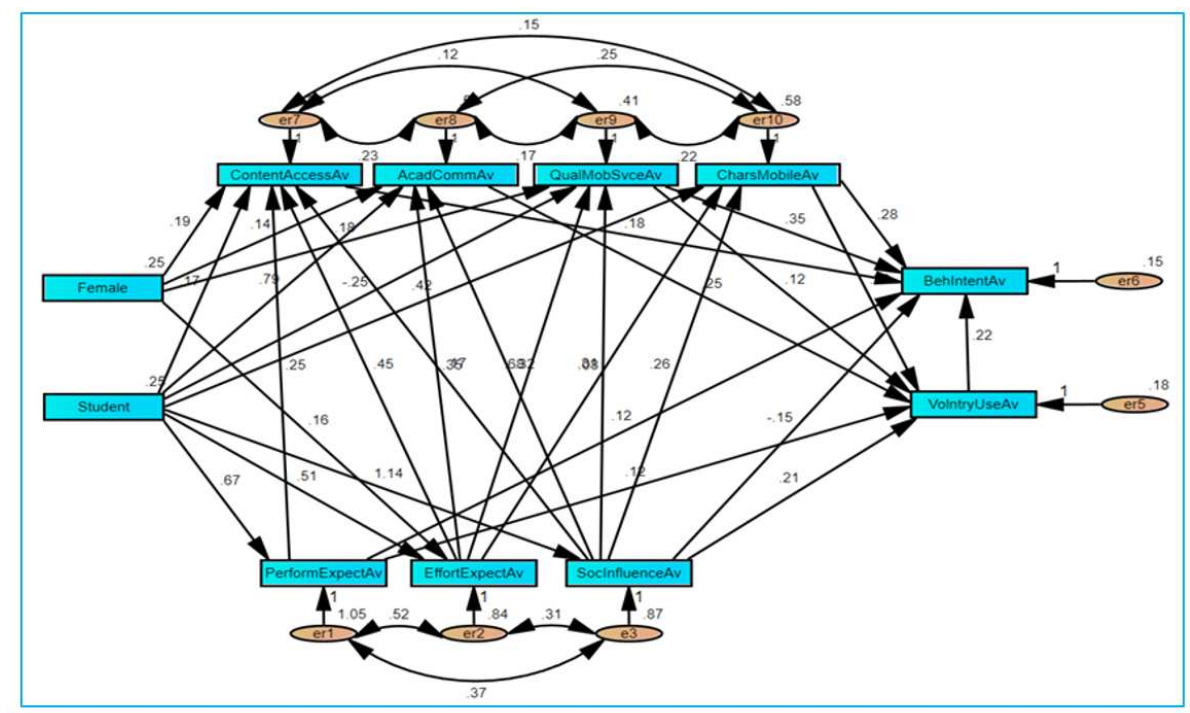

Figure 3. Parsimonious version of UTAUT extended model.

\section{Discussion}

These results reported in this study show that performance expectancy and facilitating conditions affect technology use behavior [18]. In turn, while numerous studies have reported encouraging results with respect to the integration of mobile devices into classrooms to facilitate learning and teaching [22], [23], an initial analysis of students' and lecturers' expectations and perceptions of the technology is still vital [24], [25]. 
The students' overall perceptions of mobile devices for learning were significantly more positive than the lecturers' perceptions. As shown in the results, significant differences between each group emerged in relation to performance expectancy, although both groups regarded $\mathrm{m}$ learning devices to be user-friendly, time-saving, and highly productive, which could serve to improve their overall performance. These findings accord with previous research findings that performance expectancy acts as the strongest factor relating to learner acceptance. This suggests that students have a favorable view of mobile devices within higher education learning contexts and believe that such devices enhance their learning capabilities [26].

Moreover, students have more favorable attitudes than lecturers toward m-learning devices in relation to effort expectancy, with respondents regarding mobile devices to be user-friendly and an easy way to complete academic tasks. They also exhibited understanding with respect to using such devices to interact with others. However, some lecturers indicated concerns about their understanding of how to create and develop m-learning activities. The results accord with previous research findings that effort expectancy has a significant and positive impact on learner behavioral intentions [27], [22], with learners showing greater inclination if they regard such devices as user-friendly and understandable [28].

The present study demonstrates that social influence is much more prominent for students than for lecturers. The results indicate that students particularly have a preconceived notion that the use of mobile devices will enable them to support their classmates and significantly enhance their engagement in-class activities. Moreover, students demonstrated a greater propensity to be influenced by people around them in relation to the use of mobile devices for learning compared to lecturers. These results conform to those found in previous research [29], [26]. For instance, [26] suggested that students regard their social circle as influential in regard to the adoption of such technology and concluded that the prominent figures could act as opinion-makers while integrating mobile technology. 
Overall, students appear more willing than lecturers to use mlearning technology and report having adequate resources to purchase devices, knowledge of how to use m-learning technologies, and an ability to access assistance when issues arise. These findings align with those reported in previous research, where students reported they have adequate resources to afford such devices [30], [31]. However, both groups did indicate that mobile technologies do not fit into the present learning culture and felt uncertain as to whether the university had a plan to integrate such technology into the learning programs (related to administrative resistance).

Various research studies have contended that self-efficacy and selfdirectedness have a significant and positive influence on learners' willingness to use new technology. Moreover, perceived ease and productive usage have been linked directly to self-confidence and willingness to adopt the technology [32], [33]. The results for student selfdirectedness and whether they feel they can use mobile devices to better manage their time (e.g., search for information quickly) and to learn in a self-organized environment (i.e., more autonomous learning and increased responsibility for their own learning) suggest a positive attitude and willingness in this regard. However, the results show students' present focus is more on face-to-face learning activities, which agree with results reported in previous research [32], [33], [26].

In terms of self-efficacy for mobile technology use, this is higher in students compared to lecturers. Students demonstrate a readiness to take the risk to use mobile technologies without assistance and are confident in their ability to implement the latest technology on their own assignments to complete assigned tasks for which the mobile technology is designed. Similarly, students appear to be more enthusiastic about using mobile technologies in the classroom compared to lecturers as they regard it as an efficient learning tool. The self-efficacy results agree with previous studies findings that prior use of mobile technology and self-efficacy influence student confidence and perceptions of usage ease for m-learning [32], [33]. Overall, a positive association between self-efficacy and willingness to adopt mobile technologies for learning is evident among both students and 
lecturers. Both groups agree however, that the current learning environment does not support the use of such mobile devices.

Both lecturers and students show a behavioral intention (willingness) to use mobile technology for academic purposes. In terms of frequency of use; however, the idea of frequently using mobile devices for learning is not widely supported by either group. These findings accord with those in previous research showing mobile device use in the classroom may result in unproductive behaviors, and that access to mobile devices should only be allowed when required [34].

Also of interest to this study is the internal and external factors related to m-learning (e.g., access to content, mobile device characteristics, etc.) and how willing the lecturers and students were to use mobile devices to conduct group discussions, record lectures, and provide notifications of lecture notes via mobile social network platforms, the results showed both groups had a relatively positive attitude towards these ideas. These findings accord with those reported by [34], where the researchers recommended limited access to content to avoid any possible misuse. The results also suggest that both groups regard m-learning technologies as an effective mode of academic communication. However, both groups also regard mobile technologies and face to face communication as equally important for interacting with fellow students. Reference [35] reported the same results by placing an emphasis on the effectiveness of mobile devices while communicating and interacting for educational purposes.

In relation to mobile device characteristics, both groups placed high importance on ease of navigation, followed by user-friendliness, service availability, and fast speed. However, respondents were not very concerned about the error-free demand. Other desirable characteristics included affordability, broad access, and opportunities to integrate with social networks. A small screen was not considered a desirable characteristic. These results aligned with those reported in previous research where researchers contended that ease of use and the latest characteristics could convince learners to accept a new mode of learning [36]. However, the 
findings did not accord with [37], as researchers stressed the importance of both the size and the smooth touch of the device screen. These discrepancies may be due to differences in how the specific items were measured across the studies, along with differences in the samples analyzed within the studies.

Lastly, the significance of gender in m-learning usage has been studied by many authors, with mixed results reported. Reference [26] reported gender had a significant impact, whereas [38] found no such impact. Within the current study, the multivariate tests for the role, gender, and the two-way interaction between role and gender were all significant. In terms of role, students were found to indicate significantly higher scores on 10 of the 12 scales compared to lecturers. Gender (being female) was found to significantly influence 5 of the 12 scale scores: behavioral intention, content access, academic communication, quality of mobile communication, and skills on mobile devices. Analysis of the two-way interaction between role and gender found that being a student and being female significantly influenced scores for 4 of the 12 scale scores: effort expectancy, behavioral intention, the quality of mobile communication, and skills on mobile devices. Here, the research findings differ from those reported in previous research where gender did not show any significant difference [39]. A study conducted by [40] also did not report a significant role of gender regarding m-learning usage. However, due to the limited scope of their respective studies, both researchers suggested exploring the role of gender in greater detail. The discrepancies may also be due to differences in how the specific items were measured across the studies, along with differences in the samples analyzed.

The higher student scores related to willingness and enthusiasm to engage in m-learning compared to lecturers suggest that if policymakers decide to integrate m-learning into the overall learning environment, then support from students would be greater than from lecturers. Similarly, policymakers must take into consideration that student self-directedness and both lecturers' and students' performance expectancies, social influences, 
effort expectancies, and perceptions of device characteristics were significant predictors of behavioral intention to use m-learning.

\section{Conclusion}

Overall, the findings in this study were rich and insightful, adding further clarity to our understanding of the factors determining students' and lecturers' adoption and continued use of mobile technologies for learning in higher education settings. Most students and lecturers identified the affordance of such technologies to enhance academic, informal, and teacherstudent communication pathways and for the creation and management of new knowledge as important determinants of use. However, it was also the case that aspects of the design of mobile technologies such as screen size and data storage capacity were identified by the participants as potential hindrances to use. Although both students and lecturers held generally positive perceptions of m-learning within Saudi higher education service delivery, the students overall were more receptive to the idea and to the affordances mobile technologies offer to the learning process. Regarding the integration of mobile technologies for learning into higher education settings, both students and teachers reaffirmed findings reported in previous research of the need to ensure ease of use, convenience, and the provision of organizational support for users.

\section{Acknowledgment:}

The Ministry of Education in Saudi Arabia sponsored this study. The author is thankful to all students and educators who participated in the study voluntarily.

\section{References}

[1] Mayes, T., \& De Freitas, S. (2013). Technology-enhanced learning: The role of theory. In H. Beetham, \& R. Sharpe (Eds.), Rethinking Pedagogy for a Digital Age: Designing for 21st Century Learning (2nd ed., pp. 17-30). New York, NY: Routledge.

[2] Oliver, R., Harper, B., Wills, S., Agostinho, S., \& Hedberg, J. (2013). Describing ICT based learning designs that promote quality-learning outcomes. In H. Beetham \& R. Sharpe (Eds.), Rethinking pedagogy for a 
- Examining the Determinants of Mobile Technologies use in Academic settings

digital age: designing for 21st century learning (2nd ed., pp. 102-118). New York: Routledg.

[3] Courts, B., \& Tucker, J. (2012). Using technology to create a dynamic classroom experience. Journal of College Teaching \& Learning, 9(2), 121131.

[4] Andrews, T., \& Tynan, B. (2011). Changing student learning preferences: what does this mean for the future of universities? In Proceedings ASCILITE 2011: 28th Annual Conference of the Australasian Society for Computers in Learning in Tertiary Education: Changing Demands, Changing Directions (pp. 118-122). Australasian Society for Computers in Learning in Tertiary Education (ASCILITE).

[5] Mcconatha, D., Praul, M., \& Lynch, M. J. (2008). Mobile learning in higher education: An empirical assessment of a new educational tool. TOJET: Turkish Online Journal of Educational Technology, 7(3), 15-21.

[6] Traxler, J. (2009). Learning in a mobile age. International Journal of Mobile and Blended Learning (IJMBL), 1(1), 1-12.

[7] Kukulska-Hulme, A., \& Traxler, J. (2005). Mobile teaching and learning. In A. Kukulska-Hulme, \& J. Traxler (Eds.), Mobile Learning: A Handbook for Educators and Trainers (pp. 25-44). Oxon, OX: Routledge.

[8] Liaw, S. S., Hatala, M., \& Huang, H. M. (2010). Investigating acceptance toward mobile learning to assist individual knowledge management: Based on activity theory approach. Computers \& Education, 54(2), 446-454.

[9] Chen, Y. S., Kao, T. C., \& Sheu, J. P. (2003). A mobile learning system for scaffolding bird watching learning. Journal of Computer Assisted Learning, 19(3), 347-359.

[10] Costabile, M. F., De Angeli, A., Lanzilotti, R., Ardito, C., Buono, P., \& Pederson, T. (2008). Explore! possibilities and challenges of mobile learning. In Proceedings of the SIGCHI Conference on Human Factors in Computing Systems (pp. 145-154). ACM.

[11] Tan, T. H., \& Liu, T. Y. (2004). The mobile-based interactive learning environment (MOBILE) and a case study for assisting elementary school English learning. In Advanced Learning Technologies, 2004. Proceedings. IEEE International Conference on (pp. 530-534). IEEE. 
[12] Andrews, T., \& Tynan, B. (2012). Distance learners: Connected, mobile and resourceful individuals. Australasian Journal of Educational Technology, 28(4), 565-579.

[13] Lenhart, A., Purcell, K., Smith, A., \& Zickuhr, K. (2010). Social media \& mobile internet use among teens and young adults. Millennials. Pew Internet \& American Life Project.

[14] Tapscott, D., \& Williams, A. (2010). Innovating the 21st-century university: It's time! Educause Review, 45(1), 16-29.

[15] Rozario, R., Ortlieb, E., \& Rennie, J. (2016). Interactivity and mobile technologies: An Activity Theory perspective. In D. Churchill, J. Lu, T. K.F. Chiu, \& B. Fox (Eds.), Mobile Learning Design: Theories and Application (pp. 63-82). Singapore: Springer Science.

[16] Nassuora, A. B. (2012). Students acceptance of mobile learning for higher education in Saudi Arabia. American Academic \& Scholarly Research Journal, 4(2), 1-6.

[17] Alsswey, A., \& Al-Samarraie, H. (2019). M-learning adoption in the Arab gulf countries: A systematic review of factors and challenges. Education and Information Technologies, 1-14.

[18] Venkatesh, V., Morris, M. G., Davis, G. B., \& Davis, F. D. (2003). User acceptance of information technology: Toward a unified view. MIS quarterly, 27(3), 425-478.

[19] Davis, F. D. (1989). Perceived usefulness, perceived ease of use, and user acceptance of information technology. MIS Quarterly, 13(3), 319-339.

[20] Johnson, B. \& Christensen, L. (2010). Educational Research: Quantitative, Qualitative and Mixed Approaches (4th ed.). Los Angeles; Sage.

[21] Jairak, K., Praneetpolgrang, P., \& Mekhabunchakij, K. (2009). An acceptance of mobile learning for higher education students in Thailand. Special Issue of the International Journal of the Computer, the Internet and Management, 17(3), 36.1-36.8.

[22] Nassuora, A. B. (2012). Students acceptance of mobile learning for higher education in Saudi Arabia. American Academic \& Scholarly Research Journal, 4(2), 113. 
[23] Yordanova, K. (2007). Mobile learning and integration of advanced technologies in education. In Proceedings of the 2007 International Conference on Computer Systems and Technologies (p. 92). ACM.

[24] Al-Fahad, F. N. (2009). Students' attitudes and perceptions towards the effectiveness of mobile learning in King Saud University, Saudi Arabia. TOJET: The Turkish Online Journal of Educational Technology, 8(2), 1-9.

[25] Hwang, G. J., \& Chang, H. F. (2011). A formative assessment-based mobile learning approach to improving the learning attitudes and achievements of students. Computers \& Education, 56(4), 1023-1031.

[26] Wang, Y. S., Wu, M. C., \& Wang, H. Y. (2009). Investigating the determinants and age and gender differences in the acceptance of mobile learning. British Journal of Educational Technology, 40(1), 92-118.

[27] Iqbal, S., \& Qureshi, I. A. (2012). m-learning adoption: A perspective from a developing country. The International Review of Research in Open and Distributed Learning, 13(3), 147-164.

[28] Abu-Al-Aish, A., \& Love, S. (2013). Factors influencing students' acceptance of m-learning: An investigation in higher education. The International Review of Research in Open and Distributed Learning, 14(5), 82-107.

[29] Mtebe, J. S., \& Raisamo, R. (2014). Investigating students' behavioral intention to adopt and use mobile learning in higher education in East Africa. International Journal of Education and Development using Information and Communication Technology, 10(3), 4-20.

[30] Kihoro, J. M., Oyier, P. A., Kiula, B. M., Wafula, J. M., \& Ibukah, R. W. (2013). E-learning eco-system for mobility and effective learning: A case of JKUAT IT students. In IST-Africa Conference and Exhibition (IST-Africa), 2013 (pp. 1-9). IEEE.

[31] Mtega, W. P., Bernard, R., Msungu, A. C., \& Sanare, R. (2012). Using mobile phones for teaching and learning purposes in higher learning institutions: The case of Sokoine University of Agriculture in Tanzania. In Proceedings and Report of the 5th Ubuntu Net Alliance Annual Conference (pp. 118-129).

[32] Mai, M. Y. (2015). Science Teachers' Attitudes towards Using ICT and Mobile Learning Technologies in Malaysian Schools. European Journal of Interdisciplinary Studies, 1(3), 187-196. 
[33] Theng, Y.L. (2009). Mobile learning for tertiary students: An exploratory study of acceptance of use. In G. Siemens \& C. Fulford (Eds.), Proceedings of EdMedia: World Conference on Educational Media and Technology 2009 (pp. 937-946). Association for the Advancement of Computing in Education (AACE).

[34] Karimi, A., Hashim, Y., \& Khan, N. M. (2010). Mobile learning perception and interest among higher education distance learners in Asia. Proceedings of Global Learn, 4130-4139.

[35] Rau, P. L. P., Gao, Q., \& Wu, L. M. (2008). Using mobile communication technology in high school education: Motivation, pressure, and learning performance. Computers \& Education, 50(1), 1-22.

[36] Trifonova, A. (2003). 'Mobile learning-review of the literature'. University of Trento: Department of Information and Communication Technology.

[37] Geist, E. (2011). The game changer: Using iPads in college teacher education classes. College Student Journal, 45(4), 758-769.

[38] Gwee, S., Chee, Y. S., \& Tan, E. M. (2013). The role of gender in mobile game-based learning. In D. Parsons (Ed.), Innovations in Mobile Educational Technologies and Applications (pp. 254-271). Hershey, PA: Information Science Reference.

[39] Tan, G. W. H., Ooi, K. B., Sim, J. J., \& Phusavat, K. (2012). Determinants of mobile learning adoption: An empirical analysis. Journal of Computer Information Systems, 52(3), 82-91.

[40] Lowenthal, J. N. (2010). Using mobile learning: Determinates impacting behavioral intention. The American Journal of Distance Education, 24(4), 195-206.

[41] Akour, H. (2010). Determinants of mobile learning acceptance: An empirical investigation in higher education. ERIC.

[42] Fisher, M., King, J., \& Tague, G. (2001). Development of a self-directed learning readiness scale for nursing education. Nurse Education Today, 21(7), 516-525.

[43] Ebner, M., Lienhardt, C., Rohs, M., \& Meyer, I. (2010). Microblogs in higher education-A chance to facilitate informal and process-oriented learning? Computers \& Education, 55(1), 92-100. 


\section{- Examining the Determinants of Mobile Technologies use in Academic settings}

[44] Lan, Y.-F., \& Sie, Y.-S. (2010). Using RSS to support mobile learning based on media richness theory. Computers \& Education, 55(2), 723-732.

[45] Lawlor, B., \& Donnelly, R. (2010). Using podcasts to support communication skills development: A case study for content format preferences among. https://doi.org/10.1016/j.compedu.2009.09.031

[46] Lazzari, M. (2009). Creative use of podcasting in higher education and its effect on competitive agency. Computers \& Education, 52(1), 27-34.

[47] Ng, W., \& Nicholas, H. (2009). Introducing pocket PCs in schools: Attitudes and beliefs in the first year. Computers \& Education, 52(2), 470-480.

\section{Appendix A: Survey Constructs (Alshehri, 2017)}

\begin{tabular}{|c|c|}
\hline & \\
\hline $\begin{array}{l}\text { Performance expectancy } \\
\text { (Venkatesh et al ., 2003; } \\
\text { Davis,1989; Davis et al.,1989; } \\
\text { Moore and Benbasat,1991) }\end{array}$ & $\begin{array}{l}\text { "In this research, performance expectancy refers to the } \\
\text { degree to which an individual believes that using } \\
\text { mobile technologies will help him or her to attain } \\
\text { gains in personal performance". }\end{array}$ \\
\hline $\begin{array}{l}\text { Effort Expectancy } \\
\text { (Venkatesh et al ., 2003; Davis } \\
\text { et al.,1989) }\end{array}$ & $\begin{array}{l}\text { "In this research, effort expectancy refers to the degree } \\
\text { of ease associated with use of mobile technologies for } \\
\text { learning and teaching purpose". }\end{array}$ \\
\hline $\begin{array}{l}\text { Social Influence } \\
\text { (Venkatesh et al ., 2003; } \\
\text { Ajzen, 1991; Davis et al.,1989; } \\
\text { Fishbein and Ajzen, 1975) }\end{array}$ & $\begin{array}{l}\text { "Social influence is defined as the important people } \\
\text { pressure that influences the intentions to use mobile } \\
\text { technologies." }\end{array}$ \\
\hline $\begin{array}{l}\text { Facilitating Conditions } \\
\text { (Venkatesh et al ., 2003; } \\
\text { Ajzen, 1991) }\end{array}$ & $\begin{array}{l}\text { "The degree which students/lecturers believe that } \\
\text { organizational and technical infrastructure support in } \\
\text { using mobile technologies." }\end{array}$ \\
\hline $\begin{array}{l}\text { Self-efficacy } \\
\text { (Akour, 2010) }\end{array}$ & $\begin{array}{l}\text { "Self-efficacy is defined as an individual's perception } \\
\text { of his or her ability to use mobile technologies to } \\
\text { complete an educational task". }\end{array}$ \\
\hline $\begin{array}{l}\text { Voluntary use (Vanketesh, } \\
\text { Morris, Davis, \& Davis, } \\
\text { 2003), }\end{array}$ & $\begin{array}{l}\text { "It is defined as "the extent to which potential adopters } \\
\text { [of technology] perceive the adoption decision to be } \\
\text { non- mandatory" as cited in (Dulloo, Mokashi, \& Puri, } \\
\text { 2015)". }\end{array}$ \\
\hline
\end{tabular}




\begin{tabular}{|c|c|}
\hline $\begin{array}{l}\text { Behavioral Intention } \\
\text { (Venkatesh et al., 2003; Ajzen, } \\
\text { 1991; Davis,1989) }\end{array}$ & $\begin{array}{l}\text { "In this study, the behavioral intention is defined as } \\
\text { the degree to which lecturers or students intend to use } \\
\text { mobile technologies for academic purpose in the } \\
\text { future." }\end{array}$ \\
\hline $\begin{array}{l}\text { Mobile technologies \& } \\
\text { Content Access (from the } \\
\text { presented literatures) }\end{array}$ & $\begin{array}{l}\text { "The degree which lecturers or students believe that } \\
\text { mobile technologies are suitable to be used to get } \\
\text { access to the academic materials". }\end{array}$ \\
\hline $\begin{array}{l}\text { Mobile technologies \& } \\
\text { Academic Communication } \\
\text { (from the presented literatures) }\end{array}$ & $\begin{array}{l}\text { "The degree which lecturers or students believe that } \\
\text { mobile technologies are suitable to be used in } \\
\text { academic communication". }\end{array}$ \\
\hline $\begin{array}{l}\text { Quality of Mobile } \\
\text { Service } \\
\text { Akour (2010) }\end{array}$ & $\begin{array}{l}\text { "The influence perceptions of the reliability, } \\
\text { responsiveness, quality, personalization, and security } \\
\text { of a system have on the use of mobile technologies for } \\
\text { academic purpose". }\end{array}$ \\
\hline $\begin{array}{l}\text { Skills of using Mobile } \\
\text { technology (SUM) (from the } \\
\text { presented literatures) }\end{array}$ & $\begin{array}{l}\text { "In this research, SUM or lectures' and students' } \\
\text { mobile skills refers to the degree to which an } \\
\text { individual believes that he or she has the required } \\
\text { skills to use mobile technologies to complete a task". }\end{array}$ \\
\hline $\begin{array}{l}\text { Characteristics of Mobile } \\
\text { Device (CAM) (from the } \\
\text { presented literatures) }\end{array}$ & $\begin{array}{l}\text { "The degree which individual (lecturers/students) } \\
\text { believes that mobile devices have suitable } \\
\text { characteristics to be used to undertake a specific task". }\end{array}$ \\
\hline $\begin{array}{l}\text { SDL } \\
\text { (Fisher, King, \& Tague, 2001) }\end{array}$ & $\begin{array}{l}\text { "Self-directed learning is defined in terms of the } \\
\text { amount of responsibility the learner accepts for his or } \\
\text { her own learning". }\end{array}$ \\
\hline
\end{tabular}

